\title{
A key and checklist to the Neotropical forensically important "Little House Flies" (Diptera: Fanniidae)
}

\author{
Diana Grisales $^{1 *}$, Melise C. Lecheta ${ }^{3}$, Fernando H. Aballay ${ }^{2} \&$ Claudio J.B. de Carvalho ${ }^{3}$ \\ ${ }^{1}$ Grupo de Entomologia, Instituto de Biologia, Universidad de Antioquia, Medellín, Colombia. \\ ${ }^{2}$ Laboratorio de Entomologia, IADIZA, CCT, CONICET. Avenida Adrian Ruiz Leal, CP 5500, Mendoza, Argentina. \\ ${ }^{3}$ Departamento de Zoologia, Universidade Federal do Paraná. Caixa Postal 19020, 81531-980 Curitiba, PR, Brazil. \\ *Corresponding author: E-mail: ochoa310@gmail.com
}

\begin{abstract}
Fanniidae (Insecta: Diptera) is a relatively small family (ca. 350 spp.) with five genera, of which Fannia Robineau-Desvoidy, 1830 and Euryomma Stein, 1899 have Neotropical distributions. Some of these species are almost always found in forensic studies. Forensically relevant species have been neglected, despite recent forensic studies that suggest their importance for estimating post-mortem interval (PMI). Thus, current and updated keys to identify adults or larvae on carcasses are unavailable for the most important species. While immature stages are important in estimating PMI, evidence suggests that adults (Fanniidae as well as other families) may also be useful for this purpose. Here we provide a key to males of the species of Fanniidae (found on corpses and other decomposing organic matter) with a checklist of species that have been used in forensics in the Neotropical region. The key comprises all 38 species of Fannia and Euryomma that have already been successfully used in forensics, and species that are potentially useful for estimating PMI. These records were found after reviews of the literature and data from entomological collections. Photographs and illustrations of the main characters in the key are provided.
\end{abstract}

KEY WORDS. Fannia, Euryomma, forensic entomology, PMI.

Fanniidae (Diptera: Calyptratae) is a small family comprising five genera, two of which (Fannia Robineau-Desvoidy, 1830 and Euryomma Stein, 1899) are found in the Neotropical region. In this region Fannia comprises ca 90 species (CARvalHo et al. 2003, Couri 2004, 2005, Couri \& Winagraski 2005, Domínguez 2007, Domínguez \& Aballay 2008, Wendt \& Carvalho 2009, Wendt 2010, Quiroga \& Domínguez 2010, Grisales et al. 2012b) and Euryomma has 17 species (Wendt \& Carvalho 2007, Grisales et al. 2012a). Some of these species may be useful in forensic studies, especially to estimate the post-mortem interval (PMI) (Quiroga \& Domínguez 2010, Grisales et al. 2012a, 2012b).

Other families of flies (Calliphoridae and Sarcophagidae) are most commonly used to indicate PMI. However, while the Fanniidae are less often used, many species are prevalent in decomposing carcasses and corpses (MATUSZEWSKr et al. 2010, 2011, AbalLay et al. 2012a). Because they are less abundant in corpses than other families, identification of forensically relevant species in the Fanniidae has been neglected. A recent key to the most common forensic South American flies includes Fannia but with only six species: Fannia obscurinervis (Stein, 1900), Fannia trimaculata (Stein, 1898), Fannia pusio (Wiedemann, 1830), Fannia femoralis (Stein, 1898), F. punctipennis Albuquerque, 1954, and $F$. canicularis (Linnaeus, 1761) (Carvalho \& Mello-Patiu 2008). Yet, many new species of Fannia and Euryomma found on carcasses have been described (Grisales et al. 2012a, 2012b, Domínguez \& Aballay 2008, Quiroga \& Domínguez 2010). Also, another key to newly described species of Euryomma from Colombia is the first to mention their potential for forensic importance, yet all species were collected on decomposing animal flesh (GRISALEs et al. 2012a). An additional key to species on decomposing flesh included 13 new species of Fannia (Grisales et al. 2012b). Thus, clearly these two genera may provide useful forensic information (Wolff et al. 2001, Centeno et al. 2002, Iannacone 2003, Pérez et al. 2005, Aballay et al. 2008, 2012a, 2012b, Battán Horenstein et al. 2010, PAtitucci et al. 2011).

Immature stages of insects are commonly used in the forensic study of PMI, while adults of some species may also provide useful complementary information. In most necropha- 
gous species, adults tend to arrive at carcasses after a predictable PMI (Matuszewski et al. 2010, Michaud \& Moreau 2009), hence their potential usefulness. These adults also avoid the confusion that may arise due to predation of some fly larvae on others, which may obfuscate the exact time that the first eggs were laid (ANDRADE et al. 2002, ShiAo \& Yeh 2008). In South America, during most of the forensic work involving Fanniidae, adults are collected with little attention given to the larvae. Perhaps this is not surprising, as among the newly described species of Fanniidae associated with decomposing flesh, only the third instar larvae of Fannia yunguensis has been described (QuirogA \& Domínguez 2010).

We begin to fill this gap in the forensic use of adult necrophagous Fanniidae in South America with this key as a tool that will permit identification using the sometimes difficult diagnostic characters of adult males. The male terminalia are very important because they allow the identification of species when the external structures are morphologically conserved and thus uninformative, especially among Euryomma and some Fannia. In addition to the key to identify adult males we provide a checklist of species with updated distributions.

\section{MATERIAL AND METHODS}

Diagnostic characters used in the key were based on original descriptions and examination of specimens from the following collections: DZUP - Coleção de Entomologia Pe. Jesus Santiago Moure, Curitiba, Brazil (Claudio J.B. de Carvalho), CEUA - Colección Entomológica Universidad de Antioquia, Medellín, Colombia (Marta Wolff), IADIZA - Coleccion Entomológica, Instituto Argentino de Investigaciones de Zonas Áridas, Mendoza, Argentina (Sergio A. Roig).

In the key we followed the morphological terminology of McAlpine (1981), Stuckenberg (1999), Wendt \& Carvalho (2009) and Grisales et al. (2012a, 2012b).

We include in this study all species reported as associated to decomposing bodies (human or pig), and traps baited with organic decomposing matter (fish, chicken viscera, beef and pork) from available literature as well as from collected material. Forensic references and geographical distributions of the species on the checklist were also obtained from available literature and revision of collections.

We use the following abbreviations: Head: (fr) frontal setae, (orb) orbital setae. Thorax: (acr) serial acrostichal setae, (dc) serial dorsocentral setae, (pra) pre-alar seta. Wings: (C): costal vein. Legs: (ad) anterodorsal seta, (av) anteroventral seta, (p) posterior seta, $(\mathrm{pv})$ posteroventral seta, (v) ventral seta.

A Leica DFC 500 camera was mounted on a Leica MZ16 stereomicroscope from the Rede Paranaense de Coleções Biológicas (Taxonline) to take the photographs, which were assembled using the program Auto-Montage Pro (Syncroscopy). Some of the illustrations presented here appeared previously in GRISALES et al. (2012a, 2012b).

\section{RESULTS AND DISCUSSION}

Six species of Fanniidae were identified by CarvalHo \& Mello-Patiu (2008) as the most common forensic species in South America: F. obscurinervis, F. trimaculata, F. pusio, F. femoralis, $F$. punctipennis, and $F$. canicularis. Based on our review of the literature and insect collections, we list a total of 38 species of Fanniidae of actual or potential forensic importance (that may be associated with carcasses or with decomposing organic matter) in South America, of which 29 are in Fannia and nine in Euryomma (see Checklist).

The Fanniidae included here were collected as adults because it is rare to find larval stages in collections, although a few were found. Immature stages were described or illustrated for only eight species (Table 1). Biological cycles and immature stages are unknown for the remaining South American species. Thus, further study of larvae is encouraged.

\section{Identification key to Neotropical genera of Fanniidae (adult males)}

1. Vein A2 slightly curved, (Fig. 1). Upper orbital setae usually present (Fig. 3). First presutural dorsocentral setae less than half the length of second. Bacilliform process absent (Fig. 5). Dichoptic (Fig. 3) ................................. Euryomma Stein

$1^{\prime}$. Vein A2 strongly curved, (Fig. 2). Orbital setae absent (except in F. canicularis (Fig. 4). First presutural dorsocentral seta developed, longer than half the length of the second setae. Bacilliform process usually present (Fig. 6). Usually holoptic (Fig. 4) ........................................Fannia Robineau-Desvoidy

\section{Identification key to species of Euryomma (males)}

1. Scutum with vittae (Fig. 7) ...................................................... 2

1'. Scutum without vittae (Fig. 8) .E. peregrinum (Meigen, 1826)

2. Scutum with five vittae following $a c r$ and $d c$ (Fig. 7) ...........3

2 '. Scutum with three vittae following acr and $d c$ (Fig. 9)........5

3. Wing brownish, darkened in apical third between $\mathrm{C}$ and apical half of $\mathrm{R}_{2+3}$ (Fig. 10), haltere yellowish (dark basally or not), frontal vitta dark brown ...... ... 4

3'. Wing yellowish, haltere yellowish, frontal vitta orange-red with apical margins reddish (Fig. 11) ..

E. cornuatum Grisales, Wolff \& Carvalho

4. Length of postpedicel 2.5 times the length of pedicel. Terminalia: epandrium has few, long setae, surstylus narrows apically, with few short setae on apical half, cercal plate setulose and acute apically (Fig. 13)..... ....E. uwa Grisales, Wolff \& Carvalho

4 '. Length of postpedicel 3.5 times the length of pedicel. Terminalia: epandrium has short setae, particularly on basal half, surstylus triangular, short, with few short setae on apex and inner surface, cercal plate slightly setulose and round apically (Fig. 14) ......................... guane Grisales, Wolff \& Carvalho 

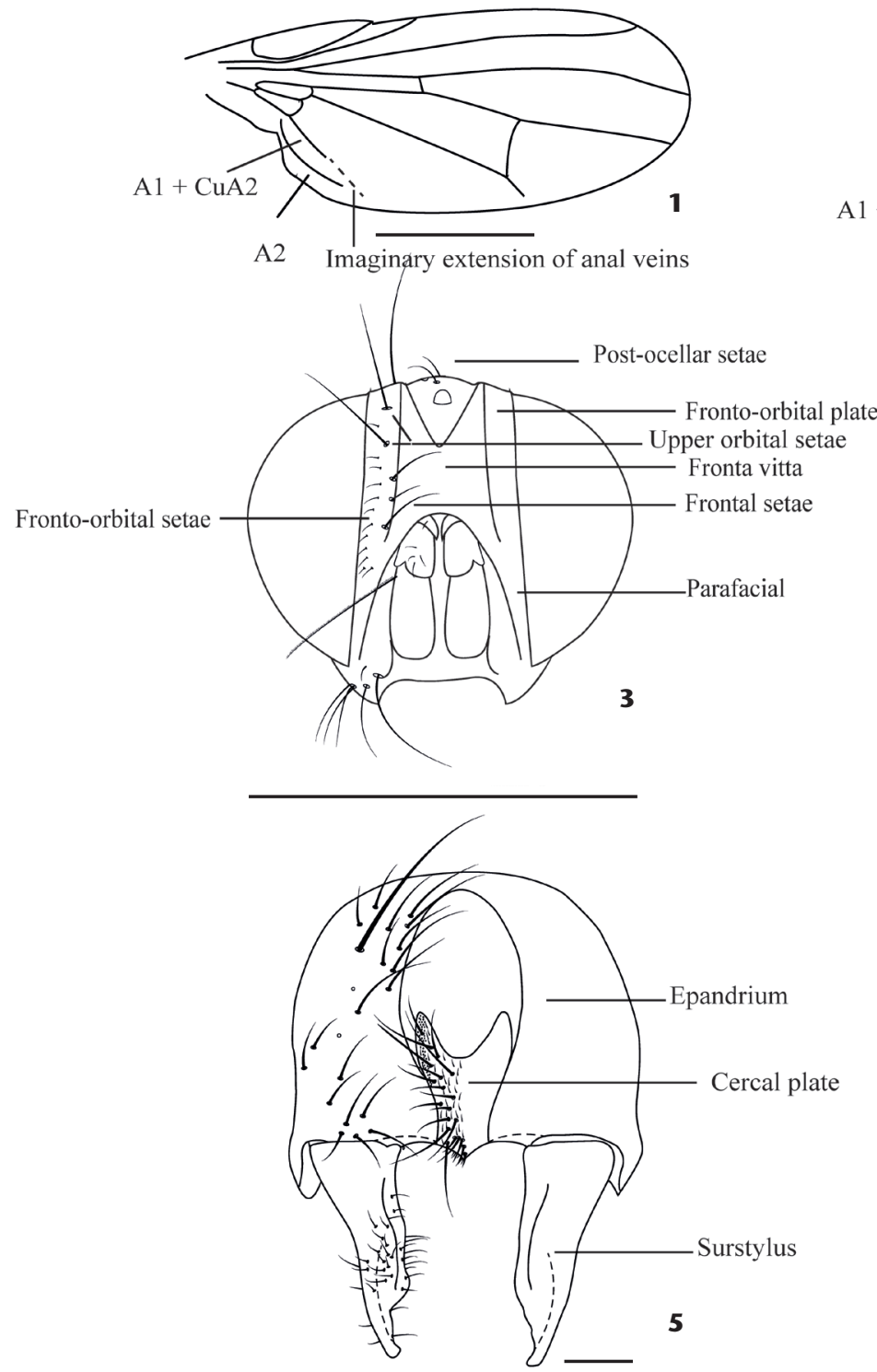

Figures 1-6. Euryomma and Fannia: (1) E. muisca, wing, dorsal view; (2) Fannia sp., wing, dorsal view; (3) E. cornuatum, head, male, frontal view; (4) Fannia sp., head, male, frontal view; (5) E. uwa, epandrium, male, dorsal view; (6) F. grandis, epandrium, male, dorsal view. Scale bars: $1-4=1.0 \mathrm{~mm}, 5-6=0.1 \mathrm{~mm}$.

Table 1. Information on immature stages of Fanniidae of forensic importance in South America.

\begin{tabular}{|c|c|c|}
\hline Species & Described or illustrated stages & References \\
\hline Euryomma peregrinum (Meigen, 1826) & Larva III & Domínguez \& Pont 2014 \\
\hline Fannia albitarsis Stein, 1911 & Egg, larva* & Albuquerque et al. 1981, Domínguez \& Pont 2014 \\
\hline Fannia canicularis (Linnaeus, 1761) & Egg, larva III & Roback 1951, Chillcott 1961, Domínguez \& Pont 2014 \\
\hline Fannia femoralis (Stein, 1898) & Larva III & ChILLCOTt 1961 \\
\hline Fannia pusio (Wiedemann, 1830) & Egg, Larva I, II, III, puparium & Chillcott 1961, Couri 1992 \\
\hline Fannia scalaris (Fabricius, 1794) & Larva III & CHILLCOTt 1961 \\
\hline Fannia trimaculata (Stein, 1898) & Egg, larva III, puparium & Albuquerque $1945^{1}$, Couri \& Carvalho 2005 \\
\hline Fannia yunguensis Quiroga \& Dominguez, 2010 & Larva III & Quiroca \& Domínguez 2010 \\
\hline
\end{tabular}

*Instar not specified. ' Here we treat the posterior leg as from F. pusio; however, CounI (1992) showed that some material in ALBUQUERQUE (1945) pertains to F. pusio and some to F. trimaculata. 

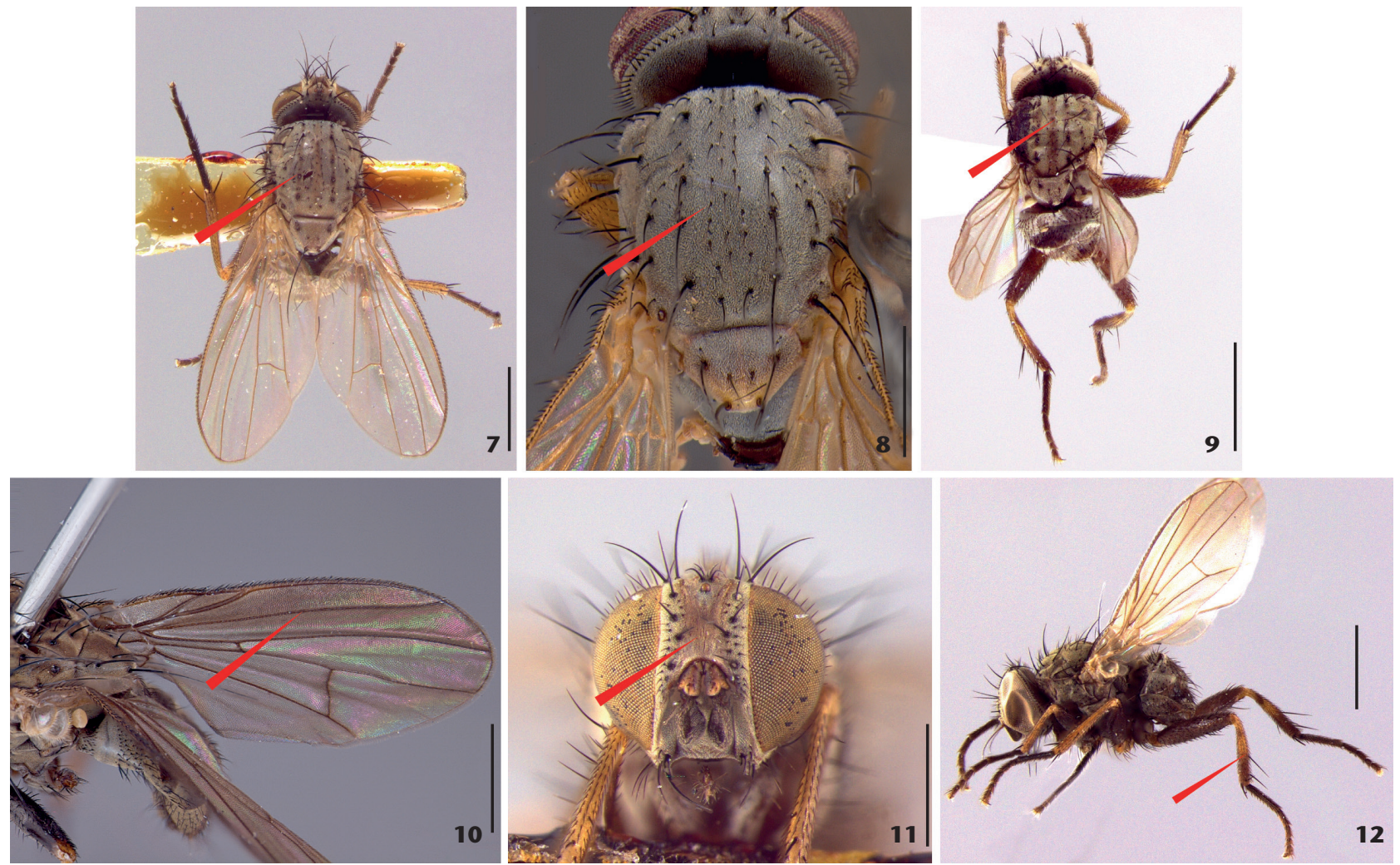

Figures 7-12. Euryomma, male: (7) E. cornuatum, dorsal view; (8) E. peregrinum, thorax, dorsal view; (9) E. tahami, dorsal view; (10) E. guane, wing, dorsal view; (11) E. cornuatum, head, frontal view; (12) E. aburrae, lateral view. Scale bars: $1.0 \mathrm{~mm}$.

5. Scape and pedicel dark brown with silvery pilosity E. carioca Albuquerque

5 '. Scape and pedicel yellow ...6 6

6. Hind tibia brown on apical half, yellow basally with a brown ring (Fig. 12), arista brown with basal third yellow. Terminalia: surstylus triangular (Fig. 15)

...7

6'. Hind tibia yellow, arista brown. Terminalia: surstylus long and narrow (Fig. 16)

7. Dorsocentral vittae on scutum conspicuous and complete, middle vitta well defined, length of postpedicel 3.6 times length of pedicel. Terminalia: surstylus fused with epandrium, cercal plate strongly concave, pointed apically, with long curved setae (Fig. 15)

\section{E. tahami Grisales, Wolff \& Carvalho}

$7 '$. Dorsocentral vittae on scutum relatively inconspicuous, well defined posteriorly to postsutural $d c$, length of postpedicel twice the length of pedicel. Terminalia: surstylus articulated with epandrium, cercal plate elongate, concave, slightly pointed apically, with short setae and apex strongly setose (Fig. 16) ..................... E. aburrae Grisales, Wolff \& Carvalho

8. Frontal vitta dark brown with apical margin yellowish, scape and pedicel brown with suture and apical margin yellowish, length of postpedicel 2.4 times the length of pedicel. Terminalia: surstylus straight with curved apex (Fig. 17), cercal plate fused on apical third (V-shaped), apex round (Fig. 17) E. chitarera Grisales, Wolff \& Carvalho

8 '. Frontal vitta dark brown, scape and generally pedicel yellow, occasionally brownish, length of postpedicel 1.5 times the length of pedicel. Terminalia: surstylus curved (Fig. 18), cercal plate fused on apical half (V-shaped), apex square (Fig. 18) .E. muisca Grisales, Wolff \& Carvalho

\section{Identification key to species Fannia (males)}

1. Hind coxa bare on posterior surface (Fig. 19)......................2

1 '. Hind coxa with setae on posterior surface (Fig. 20) ............6

2. Acr and $d c$ following pattern common in Fannia, acr 2:3 or $3: 3$, dc $2: 3$

$2^{\prime}$. Acr and $d c$ with different pattern, acr 0:0, $d c$ 0:1 or 0:2 (Figs. $22,23)$

3. Hind femur on ventral surface with preapical protuberance and large tuft of dense setae, forming a strong hook (Figs. $19,21)$ F. grandis Malloch 

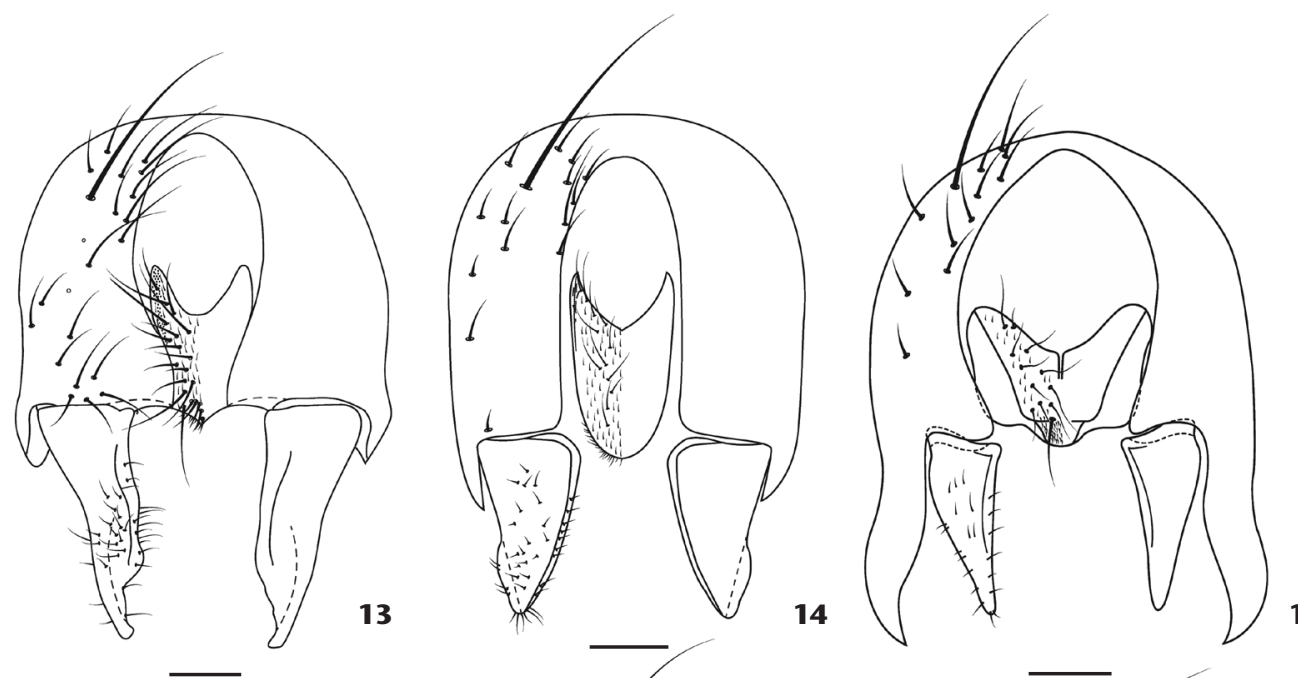

15
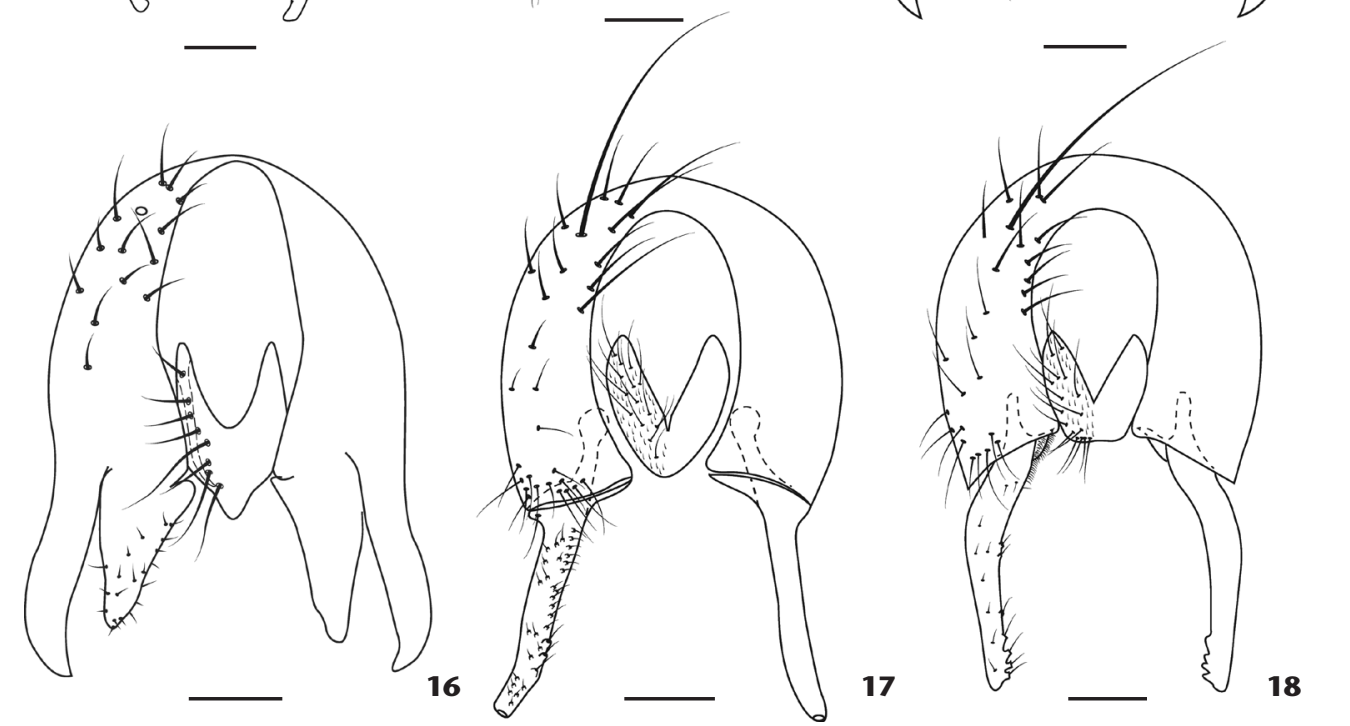

Figures 13-18. Euryomma, male, epandrium, cercal plate and surstyli, dorsal view: (13) E. uwa; (14) E. guane; (15) E. tahami; (16) E. aburrae; (17) E. chitarera; (18) E. muisca. Scale bars: $0.1 \mathrm{~mm}$.

3'. Hind femur on ventral surface with or without preapical protuberance, if protuberance present, tuft of setae not as described above.

4. Large, black, metallic blue background colour. Palpus dark brown, slightly clavate, fore tarsus with tarsomere 1 flat and wide, partially yellowish-white with broad leaf-like spine (Fig. 24), hind femur on ventral surface with strong protuberance with differentiated setae that form a tuft (Fig. 25) F. albitarsis Stein, 1911

4'. Small, greyish background color. Palpus orange-yellow, slightly spatulate, fore tarsus with tarsomere 1 brown and normal in size, hind femur on ventral surface without protuberance and weak tuft of setae on posteroventral surface (Figs. 26, 27)
5. Dc 0:1 (Fig. 23), hind femur on anteroventral surface without protuberance on apical half, ventral surface with a set of differentiated setae on the median third (Fig. 28) .....

F. quimbaya Grisales, Wolff \& Carvalho

5'. Dc 0:2 (Fig. 22), hind femur on anteroventral surface with slight protuberance on apical half, ventral surface with setae forming slight tuft with the av setae (Fig. 29). pijao Grisales, Wolff \& Carvalho

6. Mid coxa with strong hooked setae (Fig. 30), mid tibia with conspicuous preapical protuberance (Fig. 31) F. scalaris (Fabricius, 1794)

6'. Mid coxa without strong hooked setae 7

7. Abdomen black with lateral margins of tergites lighter in color, or abdomen grey and trimaculate (Fig. 32). 

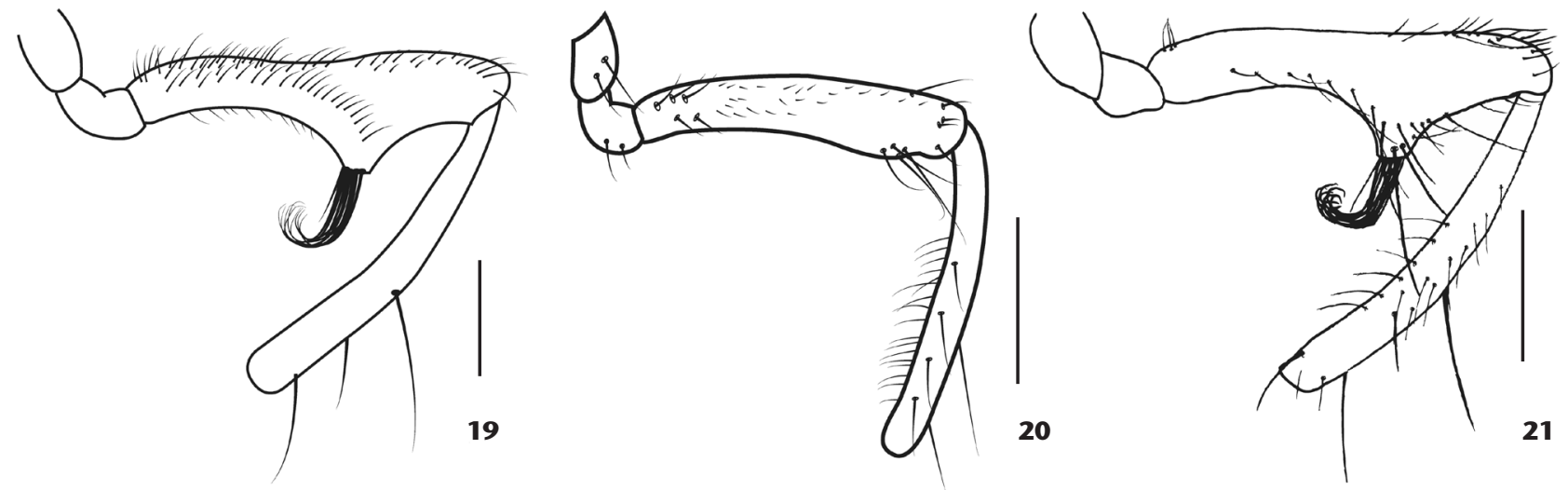

Figures 19-21. Fannia, male. (19) F. grandis, hind leg, posterior view; (20) F. pusio, hind leg, posterior view; (21) F. grandis, hind leg, anterior view. Scale bars: $1 \mathrm{~mm}$.

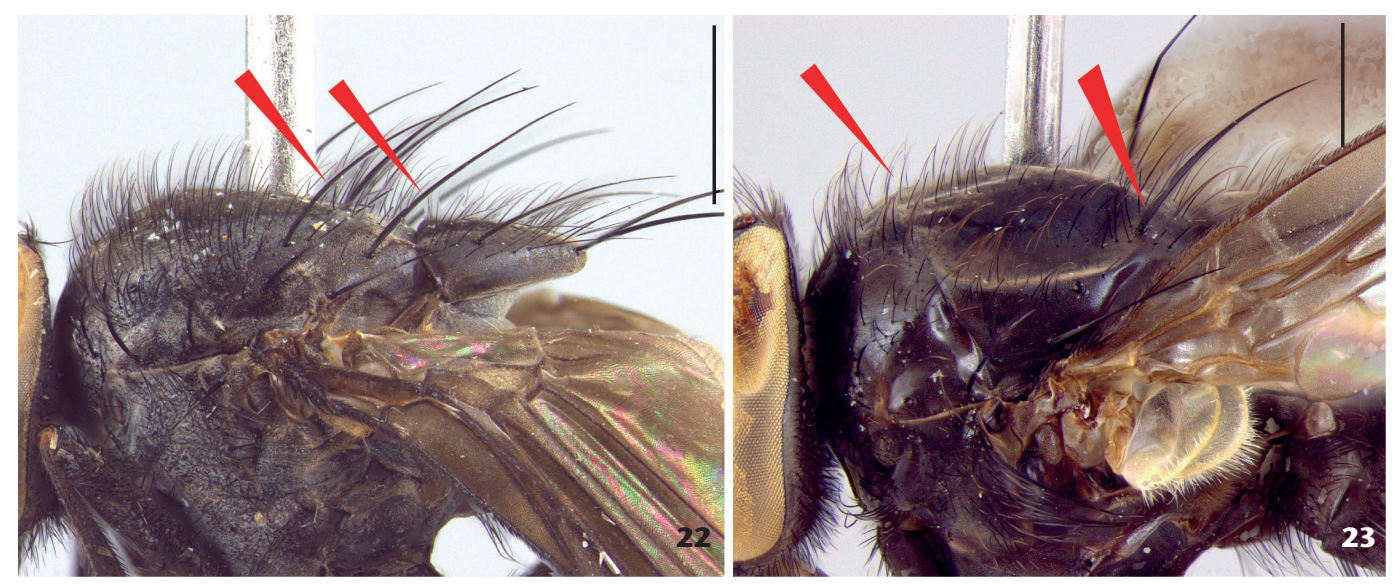

Figures 22-23. Fannia, male. (22) F. pijao, thorax, lateral view; (23) F. quimbaya, thorax, lateral view. Scale bars: $1 \mathrm{~mm}$.
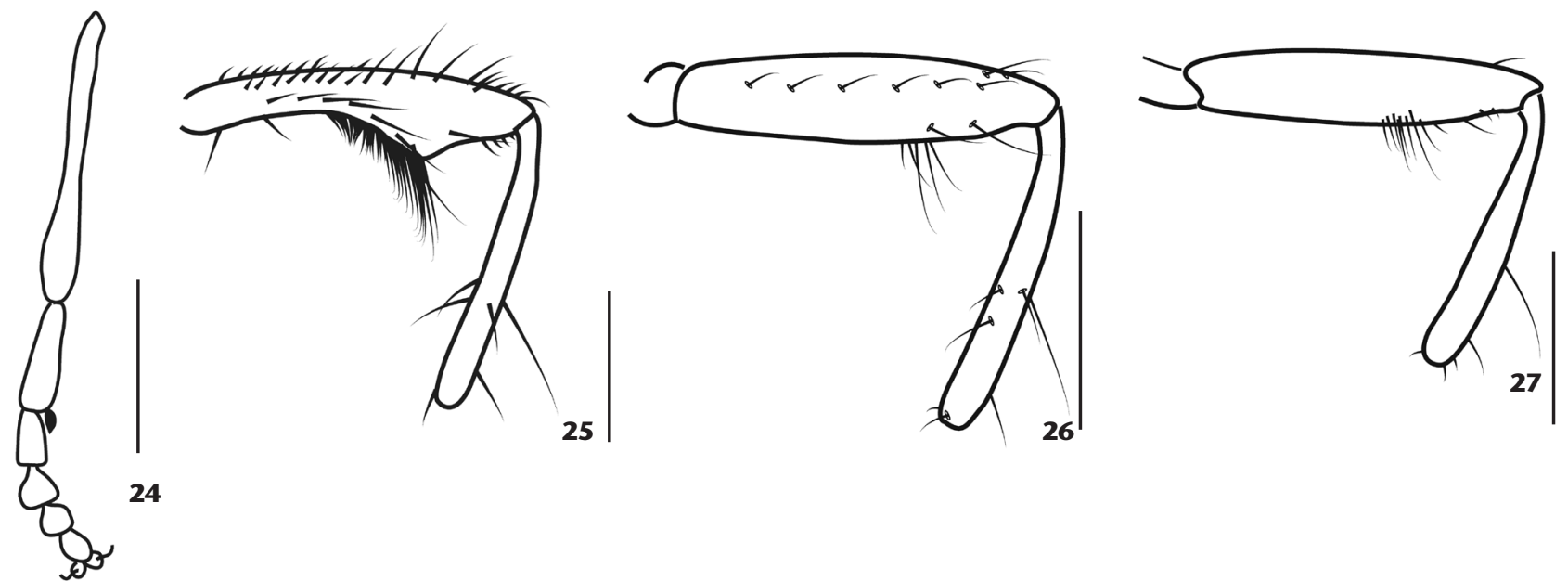

Figures 24-27. Fannia, male. (24) F. albitarsis, fore leg, fore tarsomere; (25) F. albitarsis, hind leg, anterior view; (26) F. fusconotata, hind leg, anterior view; (27) F. fusconotata, posterior view. Scale bars: $1 \mathrm{~mm}$. 

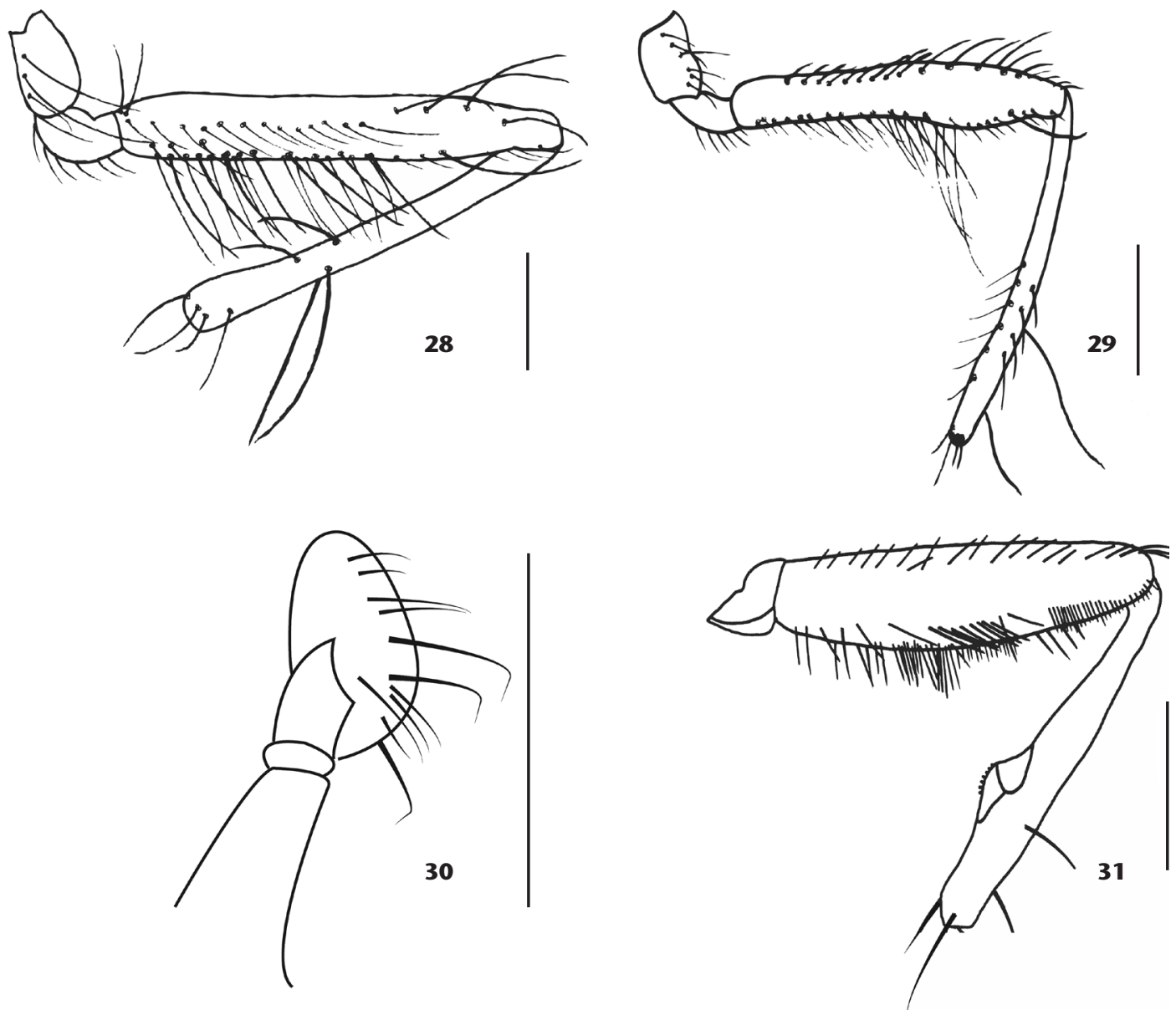

Figures 28-31. Fannia, male. (28) F. quimbaya, hind leg, anterior view; (29) F. pijao, hind leg, anterior view; (30) F. scalaris, mid tibia; (31) F. scalaris, mid leg, posterior view. Scale bars: $1 \mathrm{~mm}$.

7'. Abdomen with translucent-yellow tergites (Figs. 33, 34)..19

8. Wing brownish with upper third darker and cross veins darker (Fig. 35), abdomen black, not trimaculate, parafacial bare.. F. obscurinervis (Stein)

$8^{\prime}$. Wing yellowish, abdomen grey trimaculate, parafacial with short setae, sometimes inconspicuous (sub-group pusio)...9

9. Hind femur strongly curved (Figs. 36, 37) 10

9'. Hind femur weakly curved or straight (Fig. 38) .11

10. Eighteen frontal setae, sparse setulae on eyes, wing yellowish, hind coxa with four setae on posterior margin, hind tibia with row of 9-13 anterior setae on apical half, abdomen trimaculate..... F. chibcha Grisales, Wolff \& Carvalho

$10^{\prime}$. Eleven to twelve frontal setae, eyes bare, wing smoky, hind coxa with two setae on posterior margin, hind tibia with row of 8-9 setae on anterior surface, abdomen black

F. yunguensis Quiroga \& Dominguez, 2010

11. Hind femur with conspicuous preapical protuberance (Figs.
$39,40)$

$11^{\prime}$. Hind femur with small preapical protuberance 13

12. Hind femur with 3-4 longer bristles inserted on the swelling, hind tibia on anterodorsal surface with three median bristles (Fig. 39) .F. femoralis (Stein, 1898)

$12^{\prime}$. Hind femur with many short bristles inserted on the swelling, hind tibia on anterodorsal surface with row of five setae (Fig. 40) F. snyderi Seago

13. Hind femur with preapical ventral protuberance bearing strong setae

13 '. Hind femur with preapical ventral protuberance without setae as described above

14. Hind tibia with 1-2 rows of long setae on ventral surface (Fig. 38), hind femur on ventral surface with preapical protuberance, anteroventral and posteroventral surfaces with long and curved setae on the protuberance (Fig. 38, 42)..... F. pusio (Wiedemann, 1830) 


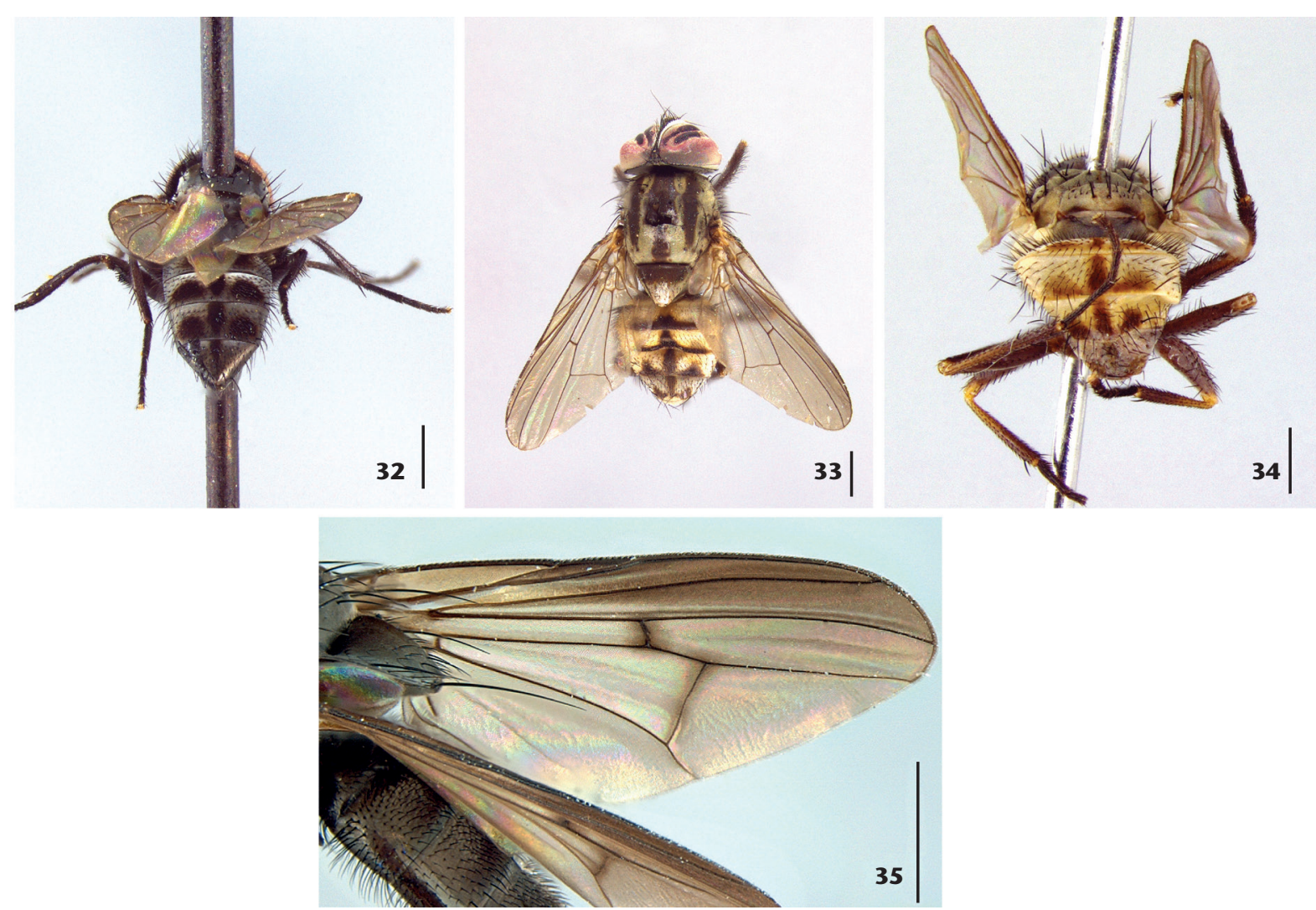

Figures 32-35. Fannia, male. (32) F. pusio, abdomen, posterior view; (33) F. grandis, dorsal view; (34) F. katios, posterior view; (35) F. obscurinervis, wing, dorsal view. Scale bars: $1 \mathrm{~mm}$.
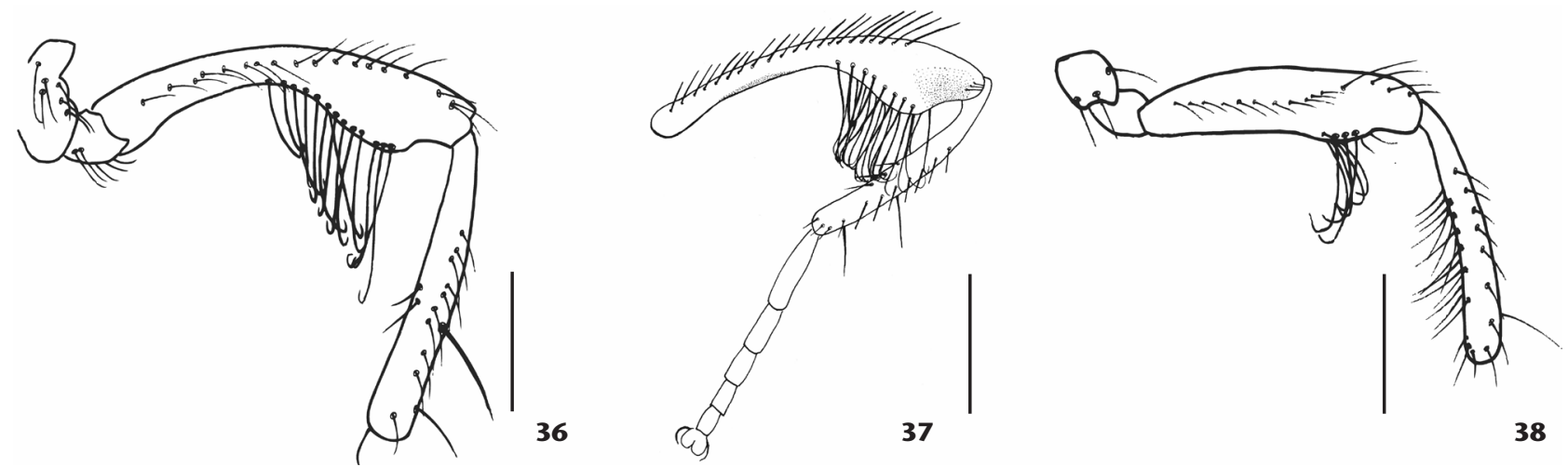

Figures 36-38. Fannia, male. (36) F. chibcha, hind leg, anterior view; (37) F. yunguensis, hind leg, posterior view; (38) F. pusio, hind leg, anterior view. Scale bars: $1 \mathrm{~mm}$.

14 '. Hind tibia without rows of long setae on ventral surface, hind femur on anteroventral surface with 3-4 preapical setae with straight apex (Fig. 41). F. sabroskyi Seago

15. Hind femur with middle third of anteroventral surface with two rows of short and straight setae and apical third with one strong seta (Fig. 43), posteroventral surface with weak preapical protuberance and row of setae that increase in length towards the apex, ending in 3-4 setae inserted on the protuberance (Fig. 44)

F. trimaculata (Stein, 1898) 

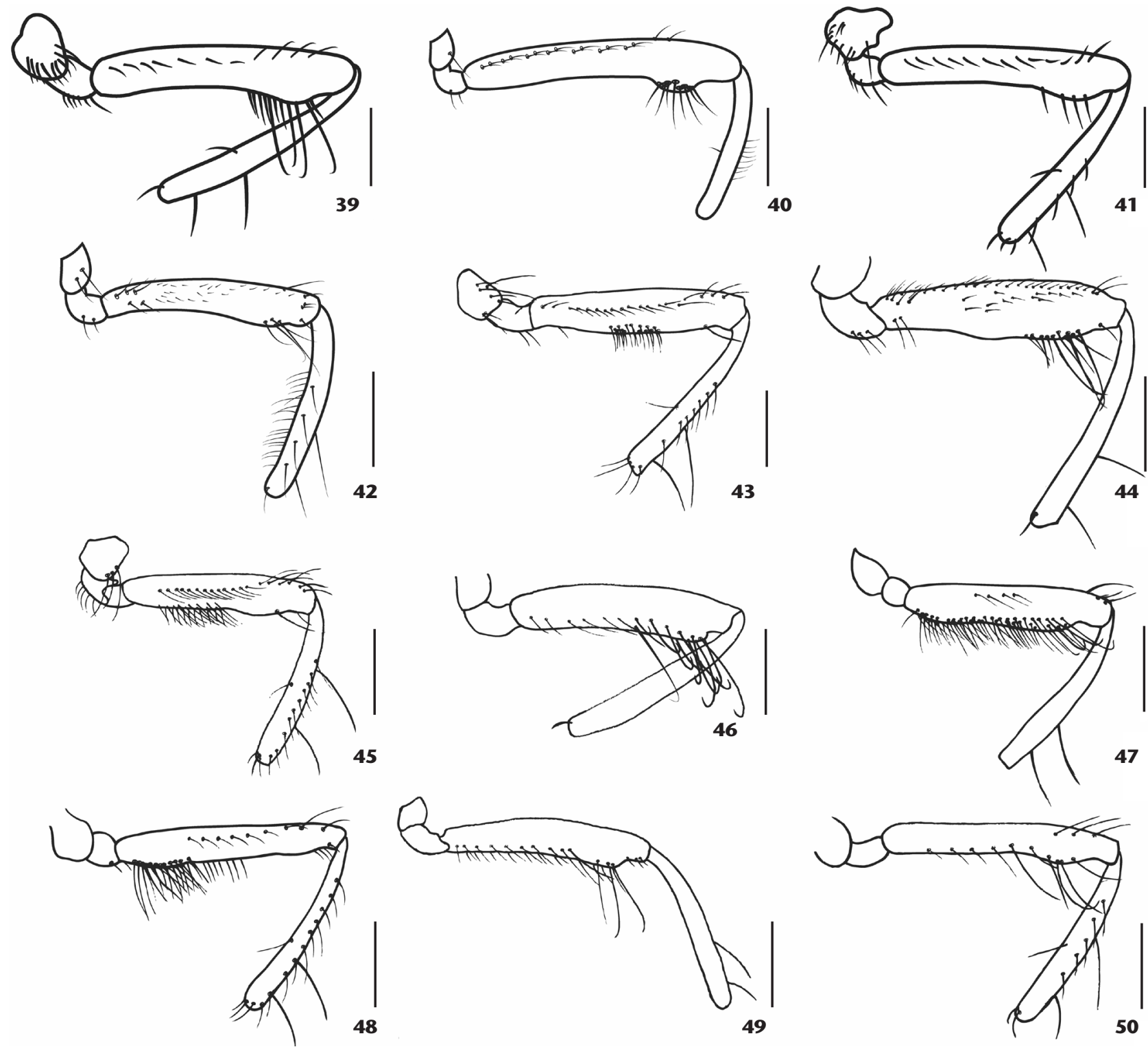

Figures 39-50. Fannia, male, hind leg. (39) F. femoralis, anterior view; (40) F. snyderi, anterior view; (41) F. sabroskyi, anterior view; (42) F. pusio, posterior view; (43) F. trimaculata, anterior view; (44) F. trimaculata, posterior view; (45) F. dodgei, anterior view; (46) F. magdalena, anterior view; (47) F. embera; posterior view; (48) F. embera; anterior view; (49) F. porce, posterior view; (50) F. porce; anterior view. Scale bars: $1 \mathrm{~mm}$.

$15^{\prime}$. Hind femur on middle third of anteroventral surface without short and straight setae, if setae are present in the area, they form a tuft with the ventral setae on basal half.

16. Hind tibia on anterodorsal surface with 10 setae (Fig. 45), hind femur on ventral surface with preapical protuberance, anteroventral surface on basal half with series of 6-7 close, strong setae, preapical seta strong (Fig. 45)...F. dodgei Seago

16 '. Hind tibia on anterodorsal surface with 5-8 setae, hind femur on ventral surface with preapical protuberance, anteroventral surface on basal half with or without a row of close, strong setae

17. Hind femur on base of ventral surface up to preapical protuberance bare, posterior surface with row of long setae that increase in length and on the preapical protuberance form a set of longer setae with weakly curved apices, apical half setulose (Fig. 46) .. F. magdalena Grisales, Wolff \& Carvalho 

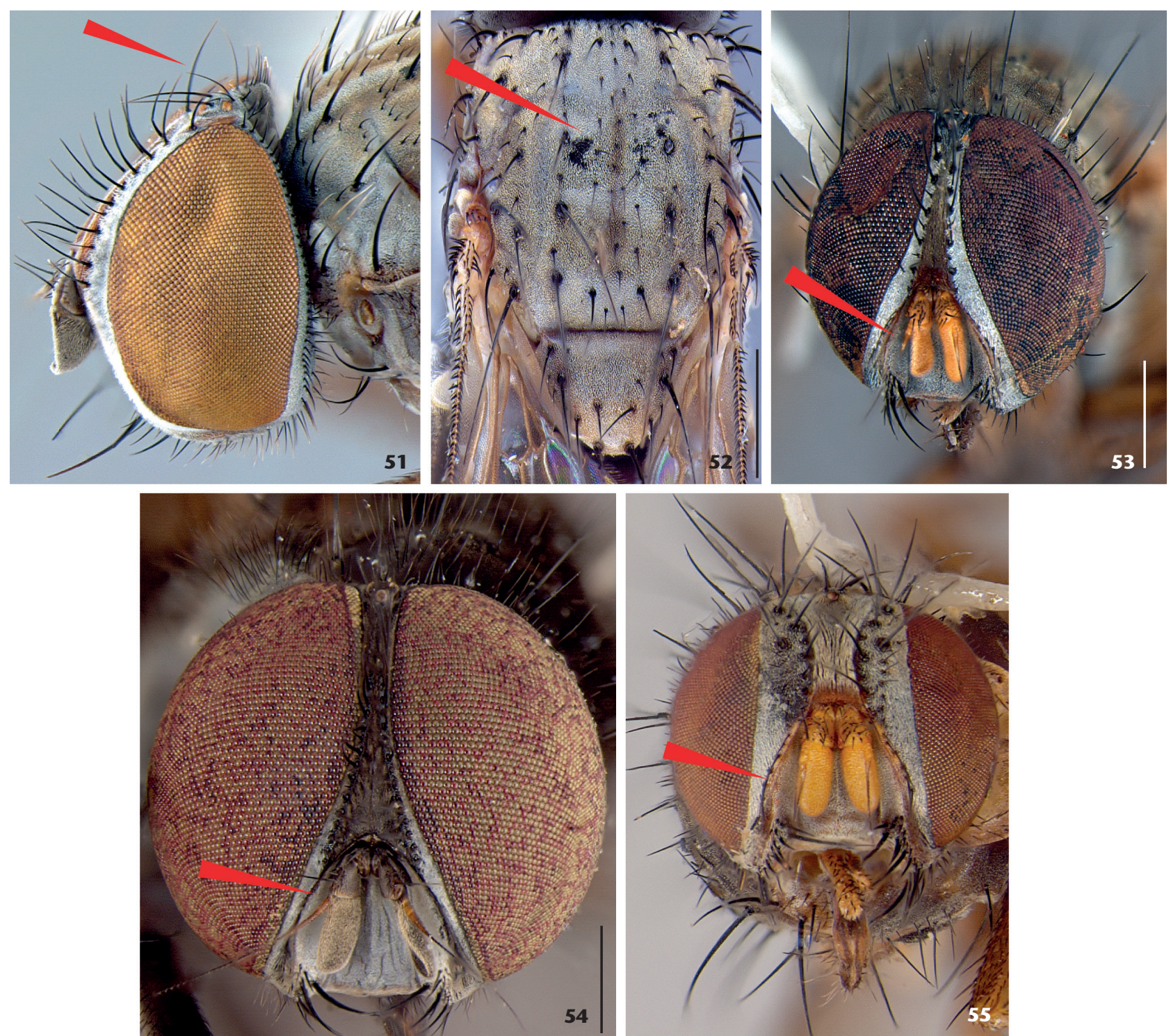

Figures 51-55. Fannia. (51) F. canicularis, male head, anterior view; (52) F. longipila, male, dorsal view; (53) F. longipila, male head, anterior view; (54) F. lamosca, male head, anterior view; (55) F. longipila, female head. Scale bars: $1 \mathrm{~mm}$.

17 . Hind femur on ventral surface completely setulose or setulose at least from base to preapical protuberance, femur not with characters described above.

18

18. Hind femur on posteroventral surface with row of long setae ending with hooked apices on protuberance (Fig. 47), ventral surface on basal half with dense setae towards the posteroventral surface where they become sparse (Fig. 48), hind tibia on anterodorsal surface with row of 6-8 setae and anteroventral surface with one median seta (Fig. 48) .. F. embera Grisales, Wolff \& Carvalho

18 '. Hind femur on apical half of posteroventral surface with row of long setae that become longer and form a tuft of setae with apex slightly curved on preapical protuberance (Fig. 49), ventral surface setulose, hind tibia on anterior surface with row of five setae (Fig. 50)

F. porce Grisales, Wolff \& Carvalho

19. Upper orb present (Fig. 51)....F. canicularis (Linnaeus, 1761)

$19^{\prime}$. Upper orb absent .....

20. Scutum with three vittae following acr and $d c$ rows (Fig. 52), scape and pedicel yellowish or brownish (Fig. 53)...........21

20 '. Scutum without vittae, scape and pedicel completely brown or with yellowish parts (Fig. 54). .25 

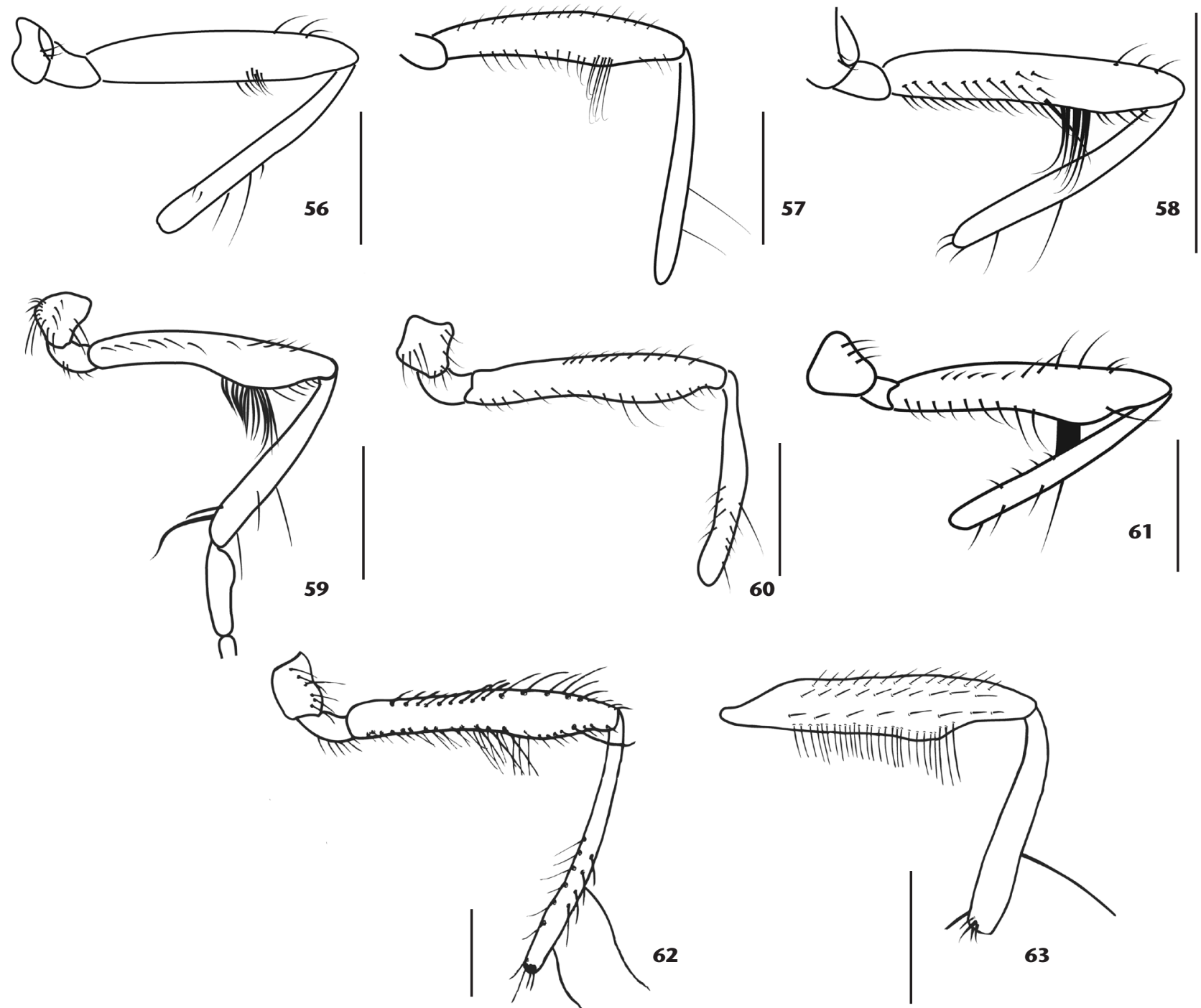

Figures 56-63. Fannia, hind leg and wing. (56) F. flavicincta, posterior view; (57) F. heydenii, posterior view; (58) F. yenhedi, posterior view; (59) F. carvalhoi, basal tarsomere; (60) F. punctipennis, anterior view; (61) F. tumidifemur, anterior view; (62) F. lamosca, anterior view; (63) F. sanihue, posterior view. Scale bars: $1 \mathrm{~mm}$.

21. Arista completely yellowish

$21^{\prime}$. Arista completely dark or part of it yellowish

22. Parafacial with setae on the ridge, $5 \mathrm{fr}$, proboscis yellowish (Fig. 55), 1 pra, fore and mid legs yellowish, hind leg brownish.

F. longipila Albuquerque

22 '. Parafacial without setae on the ridge, 9 fr, proboscis brownish, 0 pra, legs brownish

F. bahiensis Albuquerque

23. Arista black with basal third yellow, palpus black, thorax black, brownish pollinose, scutum on postsutural area with brown median vitta extending to the pleural region, apex of scutellum silver and yellowish, hind femur with approx- imately 10 long preapical $p v$, not forming a tuft (Fig. 56) ...

F. flavicincta (Stein)

$23^{\prime}$. Arista light brown and not with characters as described above.

24. Thorax with brown vitta along acrostichal line, broader brown vitta along dorsocentral lines which dissolves between $4^{\text {th }}$ and $5^{\text {th }}$ dorsocentral setae, and brown postsutural vitta along supraalar line, hind femur with one row of long and hair-like $p v$, forming a long and curled preapical tuft (Fig. 57)

F. heydenii Wiedemann

24 '. Thorax with three brown vittae along acrostichal line and dorsocentral line, hind femur on $v$ and $p v$ surface on the 
protuberance with tuft of long setae with curved apex, tuft diminishing to the base of the femur (Fig. 58)

F. yenhedi Albuquerque

25. Basal hind tarsomere wide, on $p$ surface with torsion apically (Fig. 59), hind tibia on ventral surface with very long and strong curved seta that almost reaches apex of basal tarsomere (Fig. 59) .... F. carvalhoi Couri

$25^{\prime}$. Basal tarsomere without expansion or apically torsion, hind tibia on ventral surface without setae . .26

26. Three stripes on the scutum, calypter yellowish or whitish

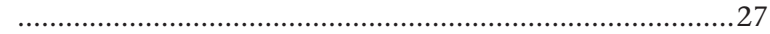

26'. Scutum without stripes, calypter brownish. .28

27. Wing brownish with transverse veins dark brown, calypter and halter yellowish, $10 \mathrm{fr}, 1$ pra, hind tibia with 1 ad setae and 5 av setae (Fig. 60)............. F. punctipennis Albuquerque

27 '. Wing yellowish with transverse veins not dark brown, calypter whitish and halter yellowish, 12 fr, 1 pra, hind tibia with 2 ad and 3-4 av (Fig. 61) .............. F. tumidifemur Stein

28. Wing with upper third brownish, hind femur with preapical protuberance on ventral surface and tuft of setae with curved apex, hind tibia with 5 av and 2 ad (Fig. 62).....

..F. lamosca Grisales, Wolff \& Carvalho

28 '. Wing without upper third brownish, hind femur with a row of $p v$ that forms long preapical tuft (Fig. 63), hind tibia with 3 av and 5 ad ................... F. sanihue Dominguez \& Aballay

\section{Checklist of the Neotropical forensically important Fanniidae}

Euryomma carioca Albuquerque, 1956: 2. Type locality: Brazil, Guanabara [= Rio de Janeiro]. References: Brazil (Linhares 1981, Almeida et al. 1985, Leandro \& D’Almeida 2005).

Euryomma cornuatum Grisales, Wolff \& Carvalho, 2012a: 816819. Type locality: Colombia, Medellín. Reference: Colombia (Grisales et al. 2012a).

Euryomma aburrae Grisales, Wolff \& Carvalho, 2012a: 808, 812-814. Type locality: Colombia, Antioquia. Reference: Colombia (Grisales et al. 2012a).

Euryomma chitarera Grisales, Wolff \& Carvalho, 2012a: 814-816. Type locality: Colombia, Norte de Santander. References: Colombia (Grisales et al. 2012a).

Euryomma guane Grisales, Wolff \& Carvalho, 2012a: 819-821. Type locality: Colombia, Santander. Reference: Colombia (Grisales et al. 2012a).

Euryomma muisca Grisales, Wolff \& Carvalho, 2012a: 821-824. Type locality: Colombia, Cundinamarca. Reference: Colombia (Grisales et al. 2012a).

Euryomma tahami Grisales, Wolff \& Carvalho, 2012a: 824-826. Type locality: Colombia, Antioquia. Reference: Colombia (Grisales et al. 2012a).

Euryomma uwa Grisales, Wolff \& Carvalho, 2012a: 826-828. Type locality: Colombia, Santander. Reference: Colombia (GrisALEs et al. 2012a).
Euryomma peregrinum (Meigen, 1826: 187). Type locality: Germany, Hamburg. References: Argentina (AbAllay et al. 2012a), Brazil (Almeida et al. 1985).

Fannia albitarsis Stein, 1911: 105. Type locality: Chile, Guayacán. References: Argentina (Perotti 1998, Aballay et al. 2012a).

Fannia bahiensis Albuquerque, 1954: 388. Type locality: Brazil, Bahia. Reference: Brazil (Gomes et al. 2002).

Fannia canicularis (Linnaeus, 1761: 454). Type locality: "Europe". References: Brazil (LINHARES 1981, Almeida et al. 1985, CARVALHO et al. 2000, LeAndro \& D'Almeida 2005, Oliveira \& Vasconcelos 2010, Vasconcelos \& Araujo 2012), Colombia (Pérez et al. 2005), Peru (Iannacone 2003).

Fannia carvalhoi Couri, 2005: 457-458. Type locality: Brazil, Rio de Janeiro. Reference: Brazil (Lecheta 2009).

Fannia chibcha Grisales, Wolff \& Carvalho, 2012b: 7-9. Type locality: Colombia, Cundinamarca. Reference: Colombia (Grisales et al. 2012b).

Fannia dodgei Seago, 1954: 4. Type locality: Panama, David. References: Colombia (Grisales et al. 2012b).

Fannia dorsomaculata Grisales, Wolff \& Carvalho, 2012b: 12-13. Type locality: Colombia, Antioquia. Reference: Colombia (Grisales et al. 2012b).

Fannia embera Grisales, Wolff \& Carvalho, 2012b: 24-25. Type locality: Colombia, Chocó. Reference: Colombia (GrISALES et al. 2012b).

Fannia femoralis Stein, 1898: 282. Type locality: USA, Louisiana. References: Argentina (ABAllay et al. 2008, BATTÁn Horenstein et al. 2010, Patitucci et al. 2011, Aballay et al. 2012a, 2012b, Battán Horenstein \& Salvo 2012, Battán Horenstein et al. 2012), Brazil (Moura et al. 2005, Lecheta 2009), Colombia (GARCIA 2010).

Fannia flavicincta Stein, 1904: 453. Type locality: Peru, Vilcanota and Colombia, Cordillera. References: Brazil (Almeida et al. 1985, Leandro \& D'Almeida 2005, Barbosa et al. 2009, 2010).

Fannia fusconotata Rondani, 1868: 27. Type locality: Argentina, Mendoza. References: Argentina (CENTENo et al. 2002, AbAllay et al. 2008, 2012a, 2012b, Patitucci et al. 2011).

Fannia grandis Malloch, 1912: 3. Type locality: Panama, Porto Bello. Reference: Colombia (Grisales et al. 2012b).

Fannia heydenii Weidemann, 1830: 429. Type locality: "Brazil". References: Argentina (Patitucci et al. 2011, Aballay et al. 2012b), Brazil AlmeIDA et al. 1985, Gomes et al. 2002).

Fannia lamosca Grisales, Wolff \& Carvalho, 2012b: 30-32. Type locality: Colombia, Antioquia. Reference: Colombia (GrISALES et al. 2012b).

Fannia longipila Albuquerque, 1954: 385. Type locality: Brazil, São Paulo. Reference: Brazil (GomEs et al. 2002).

Fannia magdalena Grisales, Wolff \& Carvalho, 2012b: 32-33. Type locality: Colombia, Antioquia. Reference: Colombia (Grisales et al. 2012b).

Fannia obscurinervis Stein, 1900: 207. Type locality: Bolivia, Songo. References: Brazil (Linhares 1981, Almeida et al. 1985, Moura et al. 1997, Wendt \& Carvalho 2009, Vasconcelos \& 
Araujo 2012), Colombia (Garcia 2010).

Fannia penicillaris Stein, 1900: 205. Type locality: Bolivia, Songo. References: Brazil (LINHAREs 1981, AlmEIDA et al. 1985, LEANDRO \& D'Almeida 2005, Lecheta 2009, Wendt \& Carvalho 2009).

Fannia pijao Grisales, Wolff \& Carvalho, 2012b: 34-36. Type locality: Colombia, Caldas. Reference: Colombia (Grisales et al. 2012b).

Fannia porce Grisales, Wolff \& Carvalho, 2012b: 36-37. Type locality: Colombia, Antioquia. Reference: Colombia (GrISALES et al. 2012b).

Fannia punctipennis Albuquerque, 1954: 319. Type locality: Brazil, Minas Gerais. References: Brazil (AlmeIDA et al. 1985, BRum et al. 1996, Moura et al. 1997, LeCheta 2009).

Fannia pusio Wiedemann, 1830: 437. Type locality: "South America". References: Brazil (Linhares 1981, Campos \& Barros 1995, Carvalho et al. 2000, Marchiori et al. 2000, Gomes et al. 2002, LEANDro \& D'Almeida 2005, Moura et al. 2005, Souza et al. 2008, Barbosa et al. 2009, 2010, Lecheta 2009, Rosa et al. 2009, Krüger et al. 2010, Oliveira \& Vasconcelos 2010, Faria et al. 2013, Vasconcelos \& Araujo 2012), Colombia (Grisales et al. 2012b).

Fannia sabroskyi Seago, 1954: 5. Type locality: Guyana, Kaieteur. References: Brazil (Almeida et al. 1985, LeCheta 2009).

Fannia sanihue Domínguez \& Aballay, 2008: 820, 822. Type locality: Argentina, Mendoza. References: Argentina (Domínguez \& Aballay 2008, Patitucci et al. 2011, Aballay et al. 2012b).

Fannia scalaris Fabricius, 1794: 332. Type locality: Denmark, "Hafniae" [= Copenhagen]. References: Brazil (AlmEIDA et al. 1985), Chile (Ortloff et al. 2012), Colombia (Wolff et al. 2004), Costa Rica (CALDERÓN-ARguedas et al. 2005).

Fannia snyderi Seago, 1954: 2. Type locality: USA, Maryland. References: Brazil (Almeida et al. 1985, LEANDro \& D'AlmeidA 2005, Rosa et al. 2009).

Fannia trimaculata Stein, 1898: 176. Type locality: North America and Jamaica. References: Brazil (LeChetA 2009), Colombia (Grisales et al. 2012b).

Fannia tumidifemur Stein, 1911: 104. Type locality: Bolivia, Sorata. References: Brazil (Almeida et al. 1985, LEANDRo \& D'AlmEIDA 2005, LECHETA 2009).

Fannia yenhedi Albuquerque, 1957: 16. Type locality: Brazil, São Paulo. References: Brazil (Linhares 1981, FARIA et al. 2013).

Fannia yunguensis Quiroga \& Dominguez, 2010: 98-99. Type locality: Argentina, Jujuy. Reference: Argentina (Quiroga \& Dominguez 2010).

\section{ACKNOWLEDGMENTS}

We are thankful to the curators of the entomological collections for facilitating access to specimens. We also thank the anonymous reviewers for their helpful comments on the manuscript. James J. Roper improved the English language and provided helpful comments. Financial support was provided by a CNPq (Brazil) postdoctoral grant to DG (process 158870/2014-0) and doctoral grant to ML. CJBC is a fellow of CNPq (process 304713/2011-2). MCD and FHA thanks to CONICET and ANPCyT (PICT 2012-0231 and PICT 2013-514) Argentina, for financial support.

\section{LITERATURE CITED}

Aballay FHA, Murúa F, Acosta JC, Centeno N (2008) Primer registro de artropodofauna cadavérica em sustratos humanos y animales em San Juan, Argentina. Revista de la Sociedad Entomológica Argentina 67: 157-163.

Aballay FH, Domínguez MC, Campón FF (2012a) Adult Fanniidae associated to pig carcasses during the winter season in a semiarid environment: Initial examination of their potential as complementary PMI indicators. Forensic Science International 219: 1-4. doi: 10.1016/j.forsciint.2011.11.019

Aballay FH, Murua AF, Acosta JC, Centeno N (2012b) Succession of Carrion Fauna in the Arid Region of San Juan Province, Argentina and its Forensic Relevance. Neotropical Entomology 41: 27-31. doi: 10.1007/s13744-011-0005-9

Albuquerque D de O (1945) Sobre Fannia trimaculata (Stein, 1897) Malloch 1913 (Diptera, Muscidae). Boletim do Museu Nacional do Rio de Janeiro 34: 1-16.

Albuquerque D de O (1954) Descrição de três espécies novas de Fannia R.-D. brasileiras, com palpos e antenas amarelas (Diptera-Muscidae). Anais da Academia Brasileira de Ciências 26: 385-394.

Albuquerque D de O (1956) Fauna do Distrito Federal. Contribuição ao conhecimento de Euryomma Stein, 1899, com descrição de uma espécie nova (Diptera, Muscidae). Boletim do Museu Nacional do Rio de Janeiro 134: 1-6.

Albuquerque D DE O (1957) Sôbre espécies de Fannia R.-D. 1830 novas ou pouco conhecidas (Diptera-Muscidae). Boletim do Museu Nacional do Rio de Janeiro 172: 1-31.

Albuquerque D de O, Pamplona D, Carvalho CJB de (1981) Contribuição ao conhecimento dos Fannia R.D., 1830 da região Neotropical (Diptera, Fanniidae). Arquivos do Museu Nacional do Rio de Janeiro 56: 9-34.

Almeida JR de, Carvalho CJB De, Malkowski SR (1985) Dípteros sinantrópicos de Curitiba e arredores (Paraná, Brasil). II. Fanniidae e Anthomyiidae. Anais da Sociedade Entomológica do Brasil 14: 277-288.

Andrade JB de, Rocha FA, Rodrigues P, Sousa GR, Faria LB, Zuben CJ, Rossi NM, Godoy WAC (2002) Larval dispersal and predation in experimental populations of Chrysomya albiceps and Cochliomyia macellaria (Diptera: Calliphoridae). Memórias do Instituto Oswaldo Cruz 97: 1137-1140.

Barbosa RR, Mello-Patiu CA de, Mello RP, Queiroz MMC de (2009) New records of calyptrate dipterans (Fanniidae, Muscidae and Sarcophagidae) associated with the decomposition of domestic pigs in Brazil. Memórias do Instituto Oswaldo Cruz 104: 923-926. doi: 10.1590/S0074-02762009000600018 Barbosa RR, Mello-Patiu CA de, Ururahy-Rodrigues A, Barbosa CG, QueIroz MMC (2010) Temporal references of ten calyptrate 
dipteran species of medicolegal importance in Rio de Janeiro, Brazil. Memórias do Instituto Oswaldo Cruz 105: 191-198. doi: 10.1590/S0074-02762010000200014

Battán Horenstein M, Salvo A (2012) Community dynamics of carrion flies and their parasitoids in experimental carcasses in central Argentina. Journal of Insect Science 12: 1-10. doi: 10.1673/031.012.0801

Battán Horenstein M, Linhares AX, Ferradas BR, García D de (2010) Decomposition and dipteran succession in pig carrion in central Argentina: ecological aspects and their importance in forensic science. Medical and Veterinary Entomology 24: 16-25. doi: 10.1111/j.1365-2915.2009.00854.x

Battán Horenstein M, Rosso B, García MD (2012) Seasonal structure and dynamics of sarcosaprophagous fauna on pig carrion in a rural area of Cordoba (Argentina): Their importance for forensic science. Forensic Science International 207: 146156. doi: 10.1016/j.forsciint.2011.10.043

Brum JGW, Vianna EES, Gentilini F, Pinto LS (1996) Fannia punctipennis (Diptera: Fanniidae), vetor de ovos da Dermatobia hominis (Oestridae: Cuterebrinae) em Pelotas, RS. Revista Brasileira de Parasitologia Veterinária 5: 59-60.

Calderón-Arguedas O, Troyo A, Solano ME (2005) Sucesión de larvas de muscoideos durante la degradación cadavérica en un bosque premontano húmedo tropical. Biomédica 16: 79-85.

Campos CFM, Barros AT (1995) Dípteros muscóides da área urbana de Corumbá, Mato Grosso do Sul, Brasil. Revista Brasileira de Biologia 55: 351-354.

Carvalho CJB de, Pont AC, Couri MS, Pamplona D (2003) A catalogue of the Fanniidae (Diptera) of the Neotropical Region. Zootaxa 219: 1-32.

Carvalho CJB de, Mello-Patiu CA de (2008). Key to the adults of the most common forensic species of Diptera in South America. Revista Brasileira de Entomologia 52: 390-406. doi: 10.1590/S0085-56262008000300012

Carvalho LML, Thyssen PJ, Linhares AX, Palhares FAB (2000) A Checklist of Arthropods Associated with Pig Carrion and Human Corpses in Southeastern Brazil. Memórias do Instituto Oswaldo Cruz 95: 135-138. doi: 10.1590/S007402762000000100023

Centeno N, Maldonado M, Oliva A (2002) Seasonal patterns of arthropods occurring on sheltered and unsheltered pig carcasses in Buenos Aires Province (Argentina). Forensic Science International 126: 63-70. doi: 10.1016/S03790738(02)00037-3

Chillcott J (1961) A Revision of the Nearctic Species of Fanniinae (Diptera: Muscidae). Canadian Entomologist 92: 1-295.

Couri MS (1992) Immature stages of Fannia pusio (Wiedemann, 1830) (Diptera, Fanniidae). Revista Brasileira de Biologia 52: 83-91. doi: 10.1590/S0101-81751990000200004

Couri MS (2004) Two new species of Fannia Robineau-Desvoidy (Diptera, Fanniidae). Brazilian Journal of Biology 64: 767770. doi: 10.1590/S1519-69842004000500005

Couri MS (2005) Fannia carvalhoi sp. nov.: a new species from
Peru (Diptera, Fanniidae). Revista Brasileira de Entomologia 49: 457-458. doi: 10.1590/S0085-56262005000400006

Couri M, Carvalho CJB DE (2005) Catálogo das espécies de Fanniidae do estado do Rio de Janeiro (Brasil). Biota Neotropica 5: 1-9. doi: 10.1590/S1676-06032005000300016

Couri MS, Winagraski E (2005) New Fannia Robineau-Desvoidy from Amazonas, Brazil and new geographical record (Diptera, Fanniidae). Revista Brasileira de Zoologia 22: 645-647. doi: 10.1590/S0101-81752005000300018.

Dominguez MC (2007) Taxonomic revision of southern South America Fannia R.-D. Papéis Avulsos de Zoolologia 47: 289-347.

Domínguez MC, Aballay F (2008) A new species of the genus Fannia Robineau-Desvoidy (Diptera: Fanniidae) collected on pig carrion in Mendoza, Argentina. Annals of Zoology 58: 819-824. doi: 10.3161/000345408X396747.

Domínguez MC, Pont AC (2014) Fanniidae (Insecta: Diptera). Auckland, Fauna of New Zealand Series vol. 71, ISBN 978-0478-34746-3, 91p.

faria lS, Paseto ML, Franco fT, Perdigão VC, Capel G, Mendes J (2013) Insects Breeding in Pig Carrion in Two Environments of a Rural Area of the State of Minas Gerais, Brazil. Neotropical Entomology 42: 216-222. doi: 10.1007/s13744012-0099-8

Garcia ECA (2010) Notes on necrophagous flies (Diptera: Calyptratae) associated to fish carrion in Colombian Amazon. Acta Amazonica 40: 397-400. doi: 10.1590/S004459672010000200018

Gomes PR, Koller WW, Gomes A, Carvalho CJB de, Zorzatto R (2002) Dípteros fanídeos vetores de ovos de Dermatobia hominis em Campo Grande, Mato Grosso do Sul. Pesquisa Veterinária Brasileira 22: 114-118. doi: 10.1590/S0100736X2002000300005

Grisales D, WolfF M, Carvalho CJB de (2012a) Neotropical Fanniidae (Insecta: Diptera): new species of Euryomma Stein from Colombia. Journal of Natural History 46: 803-829. doi: 10.1080/00222933.2011.651644.

Grisales D, WolfF M, Carvalho CJB de (2012b) Neotropical Fanniidae (Insecta, Diptera): new species of Fannia from Colombia. Zootaxa 3591: 1-46. doi: 10.11646/\%25x

IANNACONE J (2003) Artropofauna de importancia forense en un cadáver de cerdo en El Callao, Perú. Revista Brasileira de Zoologia 20: 85-90. doi: 10.1590/S0101-81752003000100010 KRÜGER RF, KIRST FD, SouZA ASB DE (2010) Rate of development of forensically-important Diptera in southern Brazil. Revista Brasileira de Entomologia 54: 624-629. doi: 10.1590/S008556262010000400014

Lecheta MC (2009) Ocorrência e chave pictórica para os machos das espécies de Fanniidae (Diptera) de interesse forense associados à carcaça de coelho durante o outono e primavera em Curitiba, Paraná. Curitiba, Bachelor's Dissertation, Programa de Pós-Graduação em Entomologia, Departamento de Zoologia, Universidade Federal do Paraná. 
Available online at: http://acervodigital.ufpr.br/bitstream/ handle/1884/27996/R\%20-\%20D\%20-\%20MELISE\%20 CRISTINE\%20LECHETA.pdf? sequence $=1$

LEANDRo MJF, D'Almeida JM (2005) Levantamento de Calliphoridae, Fanniidae, Muscidae e Sarcophagidae em um fragmento de mata na Ilha do Governador, Rio de Janeiro, Brasil. Iheringia, Série Zoologia, 95: 377-381. doi: 10.1590/S0073-47212005000400006

LinHARes AX (1981) Synanthropy of Muscidae, Fanniidae and Anthomyiidae (Diptera) in the city of Campinas, São Paulo, Brazil. Revista Brasileira de Entomologia 25: 231-243.

Malloch JR (1912) New Diptera from Panama. Smithsonian Miscellaneous Collections 59: 1-8.

McAlpIne JF (1981) Morphology and terminology - adults, p. 9-63. In: McAlpine JF, Peterson BV, Shewell GE, Teskey HJ, Vockeroth JR, Wood DM (Eds.) Manual of Nearctic Diptera. Ottawa, Agriculture Canada Research Branch, vol. 1.

Marchiori CH, Castro MEV, Paiva TCG, Teixeira FF, Silva CG (2000) Dípteros muscóides de importância médica e veterinária e seus parasitóides em Goiás. Arquivo Brasileiro de Medicina Veterinária e Zootecnia 52: 350-353. doi: 10.1590/S010209352000000400010

Matuszewski S, Bajerlein D, Konwerski S, Szpila K (2010) Insect succession and carrion decomposition in selected forests of Central Europe. Part 2. Composition and residency patterns of carrion fauna. Forensic Science International 195: 42-51. doi: 10.1016/j.forsciint.2009.11.007

Matuszewski S, Bajerlein D, Konwerski S, Szpila K (2011) Insect succession and carrion decomposition in selected forests of Central Europe. Part 3. Succession of carrion fauna. Forensic Science International 207: 150-163. doi: 10.1016/j. forsciint.2010.09.022

MEIGEN JW (1826) Systematische Beschreibung der bekannten europäischen zweiflügeligen Insekten. Hamm, vol. 5, 412p.

Michaud JP, Moreau G (2009) Predicting the visitation of carcasses by carrion-related insects under different rates of degree-day accumulation. Forensic Science International 185: 78-83. doi: 10.1016/j.forsciint.2008.12.015

Moura MO, Carvalho CJB de, Monteiro-Filho ElA (1997) A Preliminary Analysis of Insects of Medico-Legal Importance in Curitiba, State of Paraná. Memórias do Instituto Oswaldo Cruz 92: 269-274. doi: 10.1590/S0074-02761997000200023

Moura MO, Carvalho CJB de, Monteiro-Filho ELA (2005) Estrutura de comunidades necrófagas: efeito da partilha de recursos na diversidade. Revista Brasileira de Zoologia 22: 1134-1140. doi: 10.1590/S0101-81752005000400046

Oliveira TC, Vasconcelos SD (2010) Insects (Diptera) associated with cadavers at the Institute of Legal Medicine in Pernambuco, Brazil: Implications for forensic entomology. Forensic Science International 198: 97-102. doi: 10.1016/j. forsciint.2010.01.011

Ortloff A, Peña P, Riquelme M (2012) Preliminary study of the succession pattern of necrobiont insects, colonizing species and larvae on pig carcasses in Temuco (Chile) for forensic applications. Forensic Science International 222: 36-41. doi: 10.1016/j.forsciint.2012.04.022

Patitucci LD, Mulieri PR, Domínguez MC, Mariluis JC, Schnack JA (2011) Estudio preliminar de Calyptratae (Diptera) en la Reserva Natural Estricta Otamendi, Buenos Aires, Argentina. Revista de la Sociedad Entomológica Argentina 70: 157-168.

Pérez SP, Duque P, Wolff M (2005) Successional behavior and occurrence matrix of carrion-associated arthropods in the urban area of Medellín, Colombia. Journal of Forensic Science 50: 1-7. doi: 10.1520/JFS2004046

Perotti A (1998) Moscas sinántropicas (Diptera: Muscidae y Fanniidae) asociadas a producciones avícolas del centro-sudeste bonaerense. Natura Neotropicalis 29: 145-154. doi: 10.14409/natura.v2i29.3734

Quiroga NI, Domínguez MC (2010) A new species of the genus Fannia Robineau-Desvoidy (Diptera: Fanniidae) belonging to the canicularis species group, collected on pig carrion in the Yungas of the province of Jujuy, Argentina. Studies on Neotropical Fauna and Environment 45: 95-100. doi: 10.1080/01650521.2010.497994

RoNDANI C (1868) Diptera aliqua in America meridionali lecta a Prof. P. Strobel annis 1866-67 distincta et annotata, novis aliquibus descriptis. Annuario della Societàdi Naturalisti di Modena 3: 24-40.

Rosa TA, Babata Mly, Souza CM de, Sousa D de, Mello-Patiu CA de, Mendes J (2009) Dípteros de Interesse Forense em Dois Perfis de Vegetação do Cerrado em Uberlândia, MG. Neotropical Entomology 38: 859-866.

Rоваск SS (1951) A classification of muscoid Calyptrate Diptera. Annals of the Entomological Society of America 44: 327 361. doi: 10.1093/aesa/44.3.327

SEAGo JM (1954) The pusio group of the genus Fannia Robineau-Desvoidy, with descriptions of new Species (Diptera, Muscidae). American Museum Novitates 1699: 1-13.

ShiAo AF, YeH TC (2008) Larval competition of Chrysomya megacephala and Chrysomya rufifacies (Diptera: Calliphoridae): behaviour and ecological studies of two blow fly species of forensic significance. Journal of Medical Entomology 45: 785799. doi: 10.1603/0022-2585(2008)45[785:LCOCMA]2.0.CO;2

SouzA ASB DE, KIRST FD, KRÜGER RF (2008) Insects of forensic importance from Rio Grande do Sul state in southern Brazil. Revista Brasileira de Entomologia 52: 641-646. doi: 10.1590/S0085-56262008000400016

Stein P (1898) Nordamerikanische Anthomyiden. Beitrag zur Dipterenfauna der Vereinigten Staaten. Berliner entomologische Zeitschrift 42: 161-288.

STEIN P (1904) Die Amerikanischen Anthomyiden des Königlichen Museums für Naturkunde zuBerlin und des Ungarischen National-Museums zu Budapest. Annales Historico-Naturales Musei Nationalis Hungarici 2: 414-495.

STEIN P (1900) Vier neue aus Bolivia stammende Homalomyia. Arten des Ungarischen National-Museums. Természe ttudományi Füzetek 23: 205-212. 
Stein P (1911) Die von Schnuse in Südamerika gefangenen Anthomyiden. Archiv für Naturgeschichte 77: 61-189.

StUCKenBerg BR (1999) Antennal evolution in the Brachycera (Diptera), with a reassessment of terminology to the flagellum. Studia Dipterologica 6: 33-48.

VASCONCELOS SD, ARAUJO MCS (2012) Necrophagous species of Diptera and Coleoptera in northeastern Brazil: state of the art and challenges for the Forensic Entomologist. Revista Brasileira de Entomologia 56: 7-14. doi: 10.1590/S0085-56262012005000014

WENDT LD (2010) New species and new records of Fannia Robineau-Desvoidy (Diptera, Fanniidae) from the Brazilian Amazon Region. Zootaxa 2575: 38-48. doi: $10.11646 / \% 25 x$

Wendt LD, Carvalho CJB de (2007) Taxonomia de Fanniidae (Diptera) do sul do Brasil - I: nova espécie e chave de identificação de Euryomma Stein. Revista Brasileira de Entomologia 51: 197-204. doi: 10.1590/S0085-56262007000200009

Wendt LD, Carvalho CJB de (2009) Taxonomia de Fanniidae (Diptera) do sul do Brasil - II: Novas espécies e chave de identificação de Fannia Robineau-Desvoidy. Revista Brasileira de Entomologia 53: 171-206. doi: 10.1590/S0085-56262009000200003

WiedemANn CRW (1830) Aussereuropäische zweiflügelige Insekten. Hamm, Part II, 684p.
Wolff M, Uribe A, Ortiz A, Duque P (2001) A preliminary study of forensic entomology in Medellín, Colombia. Forensic Science International 120: 53-59. doi: 10.1016/S03790738(01)00422-4

Wolff M, Builes A, Zapata G, Morales G, Benecke M (2004) Detection of Parathion (O,O-diethyl O-(4-nitrophenyl) phosphorothioate) by HPLC in insects of forensic importance in Medellín, Colombia. Anil Aggrawal's Internet Journal of Forensic Medicine and Toxicology 5: 6-11.

Submitted: 22 March 2016

Received in revised form: 20 May 2016

Accepted: 14 June 2016

Editorial responsibility: Gabriel L.F. Mejdalani

Author Contributions: DG, ML, FA and CJB participated equally in the preparation of this article.

Competing Interests: The authors have declared that no competing interests exist. 